Shakespeare's
Shrine 
Shakespeare's
Shrine

The Bard's Birthplace and the 
Invention of Stratford-(apon-Kuron

\title{
Julia Thomas
}

\author{
PENN \\ UNIVERSITY OF PENNSYLVANIA PRESS \\ Philadelphia
}


A volume in the Haney Foundation Series, established in 1961 with the generous support of Dr. John Louis Haney

\section{Copyright (C) 2012 University of Pennsylvania Press}

All rights reserved. Except for brief quotations used for purposes of review or scholarly citation, none of this book may be reproduced in any form by any means without written permission from the publisher.

Published by

University of Pennsylvania Press

Philadelphia, Pennsylvania 19104-4112

www.upenn.edu/pennpress

Printed in the United States of America on acid-free paper

$$
\begin{array}{llllllllll}
10 & 9 & 8 & 7 & 6 & 5 & 4 & 3 & 2 & 1
\end{array}
$$

Library of Congress Cataloging-in-Publication Data

Thomas, Julia.

Shakespeare's shrine : the Bard's birthplace and the invention of Stratford-upon-Avon / Julia Thomas.

p. cm. (Haney Foundation series)

Includes bibliographical references and index.

ISBN: 978-0-8122-4423-6 (hardcover : alk. paper)

1. Shakespeare, William, 1564-1616-Birthplace. 2. Shakespeare, William, 1564-1616-Homes and haunts-England-Stratford-upon-

Avon. 3. Stratford-upon-Avon (England)-Description and travel.

I. Title. II. Series: Haney Foundation series

PR2916.T36 2012

$822.3^{\prime} 3-\mathrm{dc} 23$

2012002583

Frontispiece: Victorian photographers set up camp outside the Birthplace. Illustrated London News supplement, 30 April 1864. Reproduced by permission of Special Collections and Archives, Cardiff University. 
To my parents for my first visit to the Birthplace, and to Stuart for our many visits since 
